\title{
South Korea's High-Level Bilateral Meetings with African Countries Concerning Nuclear North Korea
}

\author{
Miyung Yoon, Kyudeug Hwang
}

\begin{abstract}
Many African countries have been alleged to serve North Korea as sources of hard currency, by purchasing weapons and military equipment and/or bringing military trainers and construction workers from North Korea, in violation of United Nations (UN) sanctions on North Korea. Focusing on high-level bilateral meetings between South Korea and African states during the period of October 14, 2006-December 31,2019 , this study examines the extent to which South Korea has utilized bilateral diplomacy as a tool to seek African cooperation for North Korea's denuclearization and to dissuade African countries from helping North Korea evade sanctions. We find that North Korea's denuclearization and UN sanctions, overall, have received only peripheral attention in South Korea's bilateral diplomatic discourse with African states and there is no significant difference between progressive and conservative administrations in this regard.
\end{abstract}

Keywords: South Korea, North Korea, Africa, denuclearization, United Nations sanctions, bilateral diplomacy, high-level meetings

** Miyung Yoon (yoon@hanover.edu) is Professor of International Studies and The James T. McManaman Chair in Political Science at Hanover College in the U.S. Her areas of research include women's political representation, democratization, and official development assistance in sub-Saharan Africa, as well as Korea-Africa relations. Her research appears in the Journal of Conflict Resolution, the Legislative Studies Quarterly, International Political Science Review, the Journal of Modern African Studies, Democratization, Africa Today, the Journal of Contemporary African Studies, Commonwealth \& Comparative Politics, Women's Studies International Forum, the Journal of East Asian Studies, Canadian Journal of African Studies/Revue canadienne des études africaines, Africa Spectrum, and others. She was a Senior Fulbright scholar in Korea in 2011.

* Kyudeug Hwang (kyudeug@hufs.ac.kr) is Professor at the Division of African Studies, Hankuk University of Foreign Studies, Seoul, Korea. His research interests are peace, conflict, and development in Africa, as well as Asia-Africa Relations. He published the article entitled, "Korea's Soft Power as an Alternative Approach to Africa in Development Cooperation: Beyond Economic Interest-led Perspectives of Korea-Africa Relations?" in African and Asian Studies in 2014.

The Fellowship Program of the Korea Foundation and the Faculty Development Committee of Hanover College funded the field research in South Korea for this study. The authors thank the Institute of African Studies of Hankuk University of Foreign Studies in South Korea for its support and encouragement.

The Korean Journal of International Studies Vol.19, No.2 (August 2021), 199-220

https://doi.org/10.14731/kjis.2021.08.19.2.199

(C) 2021 The Korean Journal of International Studies 


\section{INTRODUCTION}

According to the reports of the Panel of Experts on North Korea to the United Nations (UN) Security Council in 2017 and 2019, African countries (e.g., Angola, Botswana, the Democratic Republic of the Congo, Egypt, Eritrea, Ethiopia, Mozambique, Namibia, Sudan, Tanzania, Uganda, Zambia, and Zimbabwe) have helped North Korea evade a series of UN Security Council sanctions, imposed since its first nuclear test on October $9,2006,{ }^{1}$ by purchasing weapons and military equipment and/or bringing military trainers and construction workers from North Korea. They have served North Korea as "financial lifelines" (Sieff 2017). In this regard, Africa is still a battleground of the two Koreas, though the issues that dominated the North-South Korean competition in Africa during the Cold War (i.e., opening diplomatic relations with African states and gaining African votes for UN membership) are no longer relevant. Africa's help of North Korea, which stemmed from their historically rooted friendship, raises a question as to what diplomatic tools South Korea has utilized to stop that. South Korea has seen North Korean development of nuclear weapons as a threat to peace and security to the international community, particularly to the Korean peninsula and Northeast Asia, and has pressed for tough sanctions on North Korea at the UN Security Council (Choe 2016; Ministry of Foreign Affairs 2020). It has also addressed the nuclear issue at other multilateral venues (e.g., Group-20 meetings, Korea-Africa Forums, the Nuclear Security Summit of 2012, etc.) to generate international support for North Korea's denuclearization.

Like multilateral diplomacy, bilateral diplomacy is one of the tools states use to serve their national interests. It complements multilateral diplomacy and vice versa (Verdier 2008, 440). This begs the question what bilateral diplomatic efforts has South Korea made to deter North Korea's circumvention of UN sanctions in Africa, thereby strengthening the multilateral sanctions regime? Considering that economic sanctions, to be successful, necessitate a unity of the international community (Bergeijk 1989), the lack of seriousness of North Korea's African allies, who have helped North Korea generate hard currency in their countries, has undermined the effectiveness of sanctions. Furthermore, considering that Africa accounts for 54 of 193 seats in the General Assembly and 3 of 10 non-permanent seats in the Security Council, Africa's commitment to North Korea's

\footnotetext{
${ }^{1}$ The Security Council established the Panel of Experts in 2009 to gather information regarding the implementation of UN sanctions imposed on North Korea by resolutions 1718 (2006) and 1874 (2009) (United Nations Security Council 2019a). The Panel has annually reported its findings. For the series of Panel's reports, see United Nations Security Council (2019b).
} 
denuclearization and UN sanctions on the country is significant for South Korea to expand the international support for its security with regard to North Korea.

The purpose of this study is to examine South Korea's bilateral diplomatic engagement with African countries for African support on North Korea's denuclearization and UN sanctions on North Korea, focusing on high-level face-to-face meetings involving heads of government and ministers of foreign affairs of South Korea and African states. The study covers the period ensuing UN Security Council Resolution 1718, passed on October 14, 2006 in response to North Korea's first nuclear test, up to December 31, 2019. Specifically, we examine (1) the overall significance of North Korea's denuclearization and UN Security Council sanctions in high-level bilateral meetings between South Korea and African countries and (2) whether the different approaches of the progressive and conservative South Korean administrations to North Korea have had any effect on addressing those issues.

By so doing, this study explores one of the least researched topics on South Korea-Africa relations. Though a small number of studies examine South Korea-Africa relations, they mostly focus on official development assistance (ODA), trade, energy security, and/or foreign investment (Lee 2011; Hwang 2014; Yoon and Moon 2014; Kim and Gray 2016). South Korea's bilateral diplomacy with African states with respect to North Korea's denuclearization and UN sanctions on North Korea, therefore, has received little attention in the literature. We find that North Korea's denuclearization and UN sanctions, compared to economic and commercial issues, have received significantly less attention in South Korea's bilateral diplomatic discourse with African countries and there is no significant difference between the progressive and conservative administrations in this regard. This suggests that South Korea views African countries as insignificant players for its security vis-à-vis nuclear North Korea, despite its knowledge of North Korea's evasion of UN sanctions in Africa.

This article is divided into the following sections. After the introduction comes a literature review about high-level bilateral meetings as a diplomatic tool. Next is a discussion on the roots of Africa's enduring economic and military relationship with North Korea, even at the risk of potential repercussions of violating UN sanctions. The following section briefly discusses evolving South Korea-Africa relations in comparison to North Korea-Africa relations. It is followed by a discussion about the different approaches to North Korea across the South Korean administrations to examine their probable impacts on soliciting African cooperation for North Korea's denuclearization and UN sanctions on North Korea. Next is the methods we use to answer the key questions of the study. The remaining part of the article reports the findings and discusses 
why the issues of North Korea's denuclearization and UN sanctions, overall, have received only peripheral attention in South Korea's bilateral diplomacy with African countries.

\section{BILATERAL FACE-TO-FACE DIPLOMACY AS AN INTENTION SIGNALING MECHANISM: A LITERATURE REVIEW}

Diplomacy, as a tool of foreign policy, is multifaceted and entails multi-dimensional approaches involving various actors (Lee and Hudson 2004, 360 ). We cannot understate the importance of the roles high-ranking government officials play in international relations (Holmes 2013, 856). While traditional diplomacy heavily depended on residential diplomats in host countries, much of today's diplomacy involves high-ranking government officials. Among the roles they play, bilateral face-to-face meetings have been one of the most common diplomatic practices states have utilized in their relations with other states (Giauque 2001, 428). They have become "an increasingly prominent feature of contemporary diplomacy" (Lebovic and Saunders 2016, 108). The frequency of such meetings has significantly increased over time, due mainly to the advancement of communication and transportation technologies, which has made communication and travel faster and less cumbersome (Giauque 2001, 428).

Unlike multilateralism, which "requires more time and diplomatic effort to reach to an agreement," bilateralism gives "freedom of action" (Tago 2017). It also allows state-by-state based negotiations (Ibid.). Furthermore, in bilateral diplomacy, actors may pay more attention to one another than in multilateral diplomacy, where each actor has multiple actors to deal with. Bilateral diplomacy, therefore, is viewed as "the best tool to advance a country's interests" (Rozental and Buenrostro 2013, 230). States often use bilateral diplomacy to communicate their intentions, which is vital in international relations (Hall and Yarhi-Milo 2012, 561). According to Holmes (2018, 5), bilateral face-to-face meetings are an "unrivaled mechanism for intention understanding." They are useful in informing the counterpart unequivocally of one's intentions, thereby increasing the "likelihood of cooperation" (Holmes 2013, 829-830). Bilateral face-to-face interactions are not immune to criticism, however. Actors, at times, leave meetings with different interpretations of what they discussed and deceive or hide their intentions (Giauque 2001, 438; Holmes 2018, 201). Yet, no other form of interaction is more useful in sending clear signals, and "reducing uncertainty" (Holmes 2013, 829). To what extent, then, has South Korea utilized bilateral 
face-to-face meetings with African countries as an intentional signaling tool to garner their supports for North Korea's denuclearization and UN sanctions on North Korea? This is the key question this study intends to answer.

\section{NORTH KOREA AND AFRICA}

Of the two Koreas, North Korea has maintained stronger and deeper ties with African states. North Korea's strong bond with some African countries traces back to its support for their anti-colonial and liberation movements with military training and arms supplies (Owoeye 1991, 639) and the North Korea-Africa comradeship grown in the Non-Aligned Movement, in which South Korea has never been a member. Most North Korea-backed organizations came to power afterwards setting the stage for their enduring friendship with North Korea (e.g., the People's Movement for the Liberation of Angola in Angola; the South West Africa People's Organization in Namibia; the Zimbabwe African National Union-Patriotic Front in Zimbabwe; the African National Congress in South Africa, etc.) (Owoeye 1991; Bechtol 2018; Crabtree 2018).

For most other North Korea's African allies, it was the wave of socialism sweeping post-independence Africa and the Cold War divide that strengthened their bond. Before the dramatic turn of African politics toward democracy on the heels of the collapse of the Berlin Wall in 1989, "no fewer than 35 countries out of then 53 proclaimed themselves socialist at one or other point in their history" (Pitcher and Askew 2006). In Africa, where almost all countries were colonialized by the West, anti-Western North Korea looked more legitimate and appealing than South Korea, viewed as pro-Western. North Korea has closed some diplomatic posts in Africa since the 1990s due to economic hardship, but its strong bilateral ties with African countries have remained intact to this day, as demonstrated by their continuing commercial and military relations and frequent exchanges of high-level visits. This is the type of relationship South Korea deals with. Perhaps, African countries' remembrance of and gratitude for North Korea's contributions to their liberation struggles and supports for socialist regimes with military aid may have set the tone for their steady friendship.

Since Resolution 1718 on October 14, 2006, the UN Security Council passed almost a dozen resolutions with sanctions (United Nations Security Council 2019a). The Security Council has expanded the scope of sanctions over time adding more restrictions, as North Korea repeated nuclear weapons and missile tests in defiance of UN resolutions. Sanctions not only have prohibited imports and exports of military and non-military items (e.g., luxury goods, coal, fuel, 
copper, nickel, silver, zinc, food, etc.) from and to North Korea but also have included travel bans and asset freeze on individuals and entities engaged in nuclear and/or missile programs, interdiction of cargo vessels, and bans on financial transactions with North Korea. The latest Security Council resolution, in March 2020, "extended the mandate of the Panel of Experts assisting the work of the 1718 Sanctions Committee until 30 April 2021" (Security Council Report 2021). North Korea strengthened its military and commercial ties with African states to generate cash as UN sanctions went into effect. According to the report by DuPre, Kasprzyk, and Stott (2016, 3), the trade volume between North Korea and Africa has significantly increased since Security Council Resolution 1718 in 2006. While the average volume per year was $\$ 90$ million for the period of 1998-2006, it rose to $\$ 216.5$ million for the period of 2007-2015. Most African countries have been silent about North Korea's nuclear and missile tests except South Africa and Egypt, who condemned the tests (Kasprzyk n.d.). Furthermore, some of the African countries who voted in favor of the resolutions in the Security Council have been oddly among the countries reported to help North Korea evade sanctions by the Panel of Experts on North Korea (e.g., Angola, the Democratic Republic of the Congo, Egypt, Tanzania, and Uganda).

\section{SOUTH KOREA AND AFRICA}

Compared to North Korea, South Korea has maintained only marginal interest in the continent. Africa has never had a big place in its foreign policy discourse until the declaration of Korea's Initiative for Africa's Development in 2006-which became a turning point for South Korean engagement in Africa. relations with the U.S., China, Japan, Russia, and North Korea have always dominated South Korean foreign policy agenda for geopolitical reasons and overshadowed relations with other countries (Yoon and Moon 2014, 282). Since the declaration of the initiative, the volumes of trade, foreign investment, and ODA to Africa have increased (Kang 2011; Hwang 2014, 257: Kim and Gray 2016, 654-655). The number of high-level exchanges involving presidents, vice presidents, prime ministers, ministers, and special envoys has also increased. As of today, four South Korean presidents have visited the continent: Chun Doo-hwan (Kenya, Senegal, Nigeria, and Gabon in 1982), Roh Moo-hyun (Egypt, Algeria, and Nigeria in 2006), Lee Myung-bak (South Africa, the Democratic Republic of the Congo, and Ethiopia in 2011), and Park Geun-hye (Ethiopia, Uganda, and Kenya in 2016). The initiative also gave birth to such multilateral platforms as the Korea-Africa Forum, the Korea-Africa Economic Cooperation Conference, and the Korea-Africa Industry 
Cooperation Forum, all of which have been held regularly to promote the partnership between South Korea and Africa (Hwang 2014, 260-263; Yoon and Moon 2014, 283-284). South Korea has taken advantage of these multilateral platforms to generate support for North Korea's denuclearization.

South Korea's engagement in Africa also includes participation in some UN peacekeeping missions. It has deployed the South Sudan Reconstruction Support Group (Hanbit Unit) to South Sudan on March 31, 2013, following its earlier missions in West Sahara in the early 1990s and in Liberia, Côte d'Ivoire, and Darfur in the 2000s, respectively (Roehrig 2013, 635). Owing to its enhanced interest in the continent in the wake of the declaration of Korea's Initiative for Africa's Development, Africa has become the second largest recipient of South Korean ODA after Asia. But the continent has accounted for less than $4 \%$ of South Korean trade and investment (Hwang 2014, 256- 258; Yoon and Moon 2014).

Jung, Cho, and Hwang (2018) on "vote congruence between South Korea and its ODA recipients" in the UN General Assembly find that the bigger the size of South Korean ODA is, the more likely its ODA recipients vote alongside South Korea on North Korea's nuclear and human rights issues. However, the aforementioned reports of the Panel of Experts suggest that ODA has gained little traction in dampening North Korea-Africa ties and eliciting Africa's compliance with the UN sanctions regime. It has not translated into serving South Korea's security interest vis-à-vis North Korea. Paradoxically, the African countries alleged to help North Korea skirt UN sanctions have been among the top South Korean ODA recipients in Africa (e.g., Angola, the Democratic Republic of the Congo, Ethiopia, Mozambique, Tanzania, and Uganda)! ${ }^{2}$ This irony implies that South Korea may have needed active bilateral diplomatic efforts to clearly communicate its intentions to turn the tide in its favor in Africa. As such, the country has held a series of high-level bilateral meetings since 2006 to discuss "the future course of action in response to the North's nuclear test" (Ministry of Foreign Affairs, Diplomatic White Paper 2007, 37).

\section{APPROACHES TOWARD NORTH KOREA ACROSS ADMINISTRATIONS}

South Korea has alternated hard- and soft-line stances on North Korea, oscillating between progressive and conservative administrations. Have the different approaches to North Korea, then, affected South Korea's will to address

\footnotetext{
${ }^{2}$ For ODA disbursement data for each African country, see OECD (2019).
} 
Africa's support for North Korea's denuclearization and compliance with UN sanctions on North Korea? While the Roh Moo-hyun (February 25, 2003-February 24, 2008) and Moon Jae-in (May 10, 2017-) administrations have been labeled as progressive and conciliatory to the North, the Lee Myung-bak (February 25, 2008-February 24, 2013) and Park Geun-hye (February 25, 2013-March 10, 2017) administrations have been viewed as conservative and uncompromising to the North.

Roh Moo-hyun stressed peaceful co-existence on the Korean peninsula through continued economic cooperation and humanitarian aid (Kim 2006, 38-43). Roh's policy toward the North, known as the Peace and Prosperity Policy, was to gain security concessions with economic rewards (Cho 2018, 25). Roh visited Pyongyang on October 2-4, 2007 for an inter-Korea summit with Kim Jong Il. His administration continued to help North Korea with cash and food even after North Korea's first nuclear test on October 9, 2006 (Park 2008, 8).

The Lee Myung-bak administration, which marked a significant shift from Roh's conciliatory approach, put forth the policy of "Vision, 3,000 through Denuclearization and Openness" (Delury 2013, 156). The initiative promised to help North Korea achieve a per capita income of $\$ 3,000$, but only in return for denuclearization (Park 2008, 6). Therefore, denuclearization was the prerequisite for "economic cooperation" (Delury 2013, 156). He responded to North Korea's provocations (e.g., North Korea's second nuclear test in 2009 and the sinking of the Cheonan, a South Korean warship, in 2010) with calls for further international sanctions (Moon 2011, 5-6). As a result, inter-Korean "non-military interaction" was at a low ebb during his administration (Ibid., 11). The Park Geun-hye administration also took a hardline stance on the North. She introduced Trustpolitikto build trust between the two Koreas early in her term. Inter-Korean relations, however, evolved into hostilities that culminated in the end of economic cooperation in the Kaesong Industrial Complex in February 2016 on the heels of North Korea's fourth nuclear test in January 2016. Park decided to deploy Terminal High Altitude Area Defense (THAAD) in 2016 in response to North Korean nuclear threats.

Moon Jae-in, the protégé of the Sunshine Policy of President Kim Dae-jung (1998-2003) and the Peace and Prosperity Policy of Roh Moo-hyun, has pursued a two-pronged approach, which consists of sanctions and dialogue. However, he has favored engagement with the North, as exemplified by the three inter-Korea summits in 2018 (Haggard 2017, 48; Kim 2018, 165). His administration has put forth the "Resolution of the North Korean Nuclear Issue, Establishment of Lasting Peace, and Development of Sustainable Inter-Korean Relations and Realization of a New Economic Community on the Korean Peninsula" as a policy goal 
(Ministry of Foreign Affairs, Diplomatic White Paper2018, 39-40). On July 6, 2017, Moon declared in Berlin that South Korea does not pursue peace through North Korea's collapse and "artificial unification" and pursues "denuclearization that guarantees security of the North Korean regime" (Ibid., 29). Conservative governments tend to emphasize defense and national security, and we assume that the Lee and Park administrations were more likely to press for those issues in bilateral meetings with African states.

\section{METHODS}

To compile meetings and to examine the subjects of each meeting, we use volumes of Chronology of Diplomacyand Diplomatic White Paper of the Ministry of Foreign Affairs, as well as press releases and briefings of the Ministry of Foreign Affairs and Cheong Wa Dae (Blue House). We include only official bilateral meetings of incumbent heads of government and ministers of foreign affairs for a few reasons. First, they are the most significant players of foreign policy and have a broad "latitude of discretion" in setting the diplomatic discourse (Cordier 1963, 4). Second, while most other high-level officials deal with specific subjects associated with their positions, heads of government and foreign ministers cover multiple issues, including security issues. The subjects they discuss with foreign leaders, therefore, are good indicators of a country's diplomatic priorities. Last, the contents of the meetings involving other high-level officials are unavailable. High-level bilateral meetings have been held in various settings. Particularly, multilateral meetings have been instrumental in facilitating bilateral meetings. Thus, we also include bilateral meetings held on the sidelines of multilateral meetings. We rely on the information available in public, as the details of each meeting become public only after the passage of 30 years of time. Though these sources may not offer detailed discussions of each meeting, they identify at least the key subjects of each meeting.

To assess the level of attention to North Korea's denuclearization and UN sanctions, bilateral meetings with no evidence of discussing either issue are coded 0 . Meetings that included broad discussions on the precarious security situation on the Korean peninsula brought about by North Korea's nuclear and missile tests are coded 1, as South Korea has made efforts to enhance African awareness of the security threat posed by the nuclear North. Those seeking African support for North Korea's denuclearization and compliance with UN Security Council resolutions are coded 2. Meetings for which no information is available about the subjects are denoted as missing. 


\section{FINDINGS}

\section{North Korea's denuclearization and UN sanctions}

We find that seeking cooperation for North Korea's denuclearization and UN sanctions from Africa is of peripheral interest to South Korea. A total of 47 summits and 70 foreign ministerial meetings have taken place between South Korea and African states during the temporal domain of this study (Figure 1). Korea's bilateral high-level diplomacy with African states was most active in 2016, while least active in 2007, 2008, and 2018 (Figure 1).

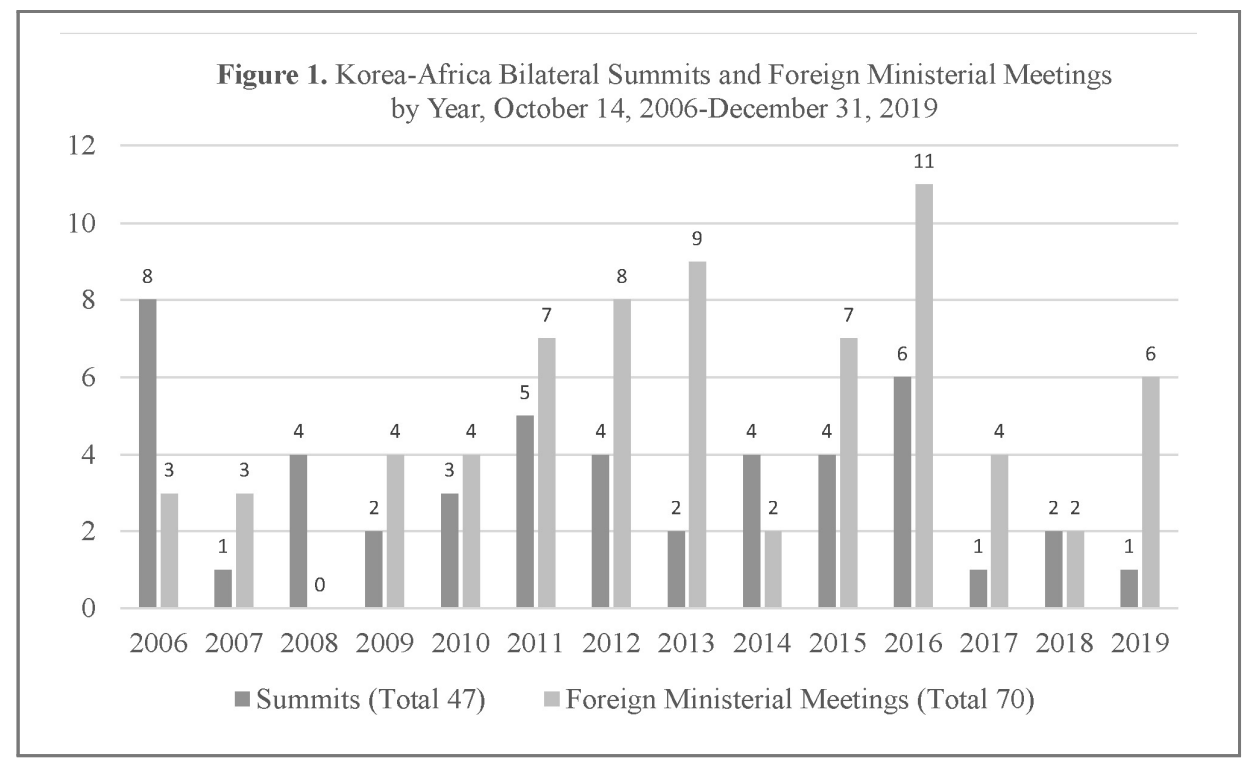

Our content analysis of the meeting subjects reveals that containing North Korea's military and economic ties with African countries has taken a back seat, while economic and development cooperation has received much attention. Specifically, such subjects as trade, investment, energy, natural resources, human resources, sharing South Korea's development experience, food and water security, ODA, participation of South Korean companies in infrastructure construction projects, and taxation have dominated most bilateral summits and foreign ministerial meetings. Some bilateral summits (10.64\%) and foreign ministerial meetings (15.71\%), along with other issues, have discussed security challenges on the Korean peninsula in broad terms. However, only a handful of 
summits (23.40\%) and foreign ministerial meetings (31.43\%) have unequivocally brought up North Korea's denuclearization and the implementation of UN sanctions on North Korea in an effort to seek African cooperation (Table 1).

Table 1. Korea-Africa Bilateral Summits and Foreign Ministerial Meetings

by Level of Security Discussion: October 14, 2006-December 31, 2019

\begin{tabular}{ccc|ccc}
\hline \multicolumn{3}{c|}{ Summits } & \multicolumn{3}{c}{ Foreign Ministerial Meetings } \\
\hline Level & Frequency & Percentage & Level & Frequency & Percentage \\
\hline 0 & 28 & $59.57 \%$ & 0 & 29 & $41.43 \%$ \\
1 & 5 & $10.64 \%$ & 1 & 11 & $15.71 \%$ \\
2 & 11 & $23.40 \%$ & 2 & 22 & $31.43 \%$ \\
Missing & 3 & $6.38 \%$ & Missing & 8 & $11.43 \%$ \\
\hline Total & 47 & $100 \%$ & Total & 70 & $100 \%$ \\
\hline
\end{tabular}

Notes: 0 refers to meetings with no discussion either on denuclearization or UN sanctions; 1, meetings involving a broad discussion on the security situation on the Korean Peninsula; and 2, meetings involving a discussion seeking African cooperation for North Korea's denuclearization and compliance with UN sanctions on North Korea.

These findings raise the question of why South Korea's bilateral meetings with African countries have put North Korea's denuclearization and African compliance with UN sanctions on the back burner, notwithstanding the unfaltering military and economic ties between North Korea and African countries, while economic and commercial issues have continued to receive much attention. We would expect seeking African support for these security issues to stand front and center in South Korean diplomacy toward Africa, considering the African helping hand to North Korea. What can explain this unanticipated tendency? First, given South Korea's four-power diplomacy centering on the US, China, Japan, and Russia in dealing with the North Korean nuclear issue, South Korea may have viewed African countries as marginally important for peace and security on the Korean peninsula. To deal with North Korea's nuclear endeavor, South Korea had relied on the Six-Party Talks (the two Koreas, the U.S., China, Japan, and Russia) - set up in August 2003 in response to North Korea's departure from the Nuclear Non-Proliferation Treaty. Though the Six-Party Talks have come to a halt since North Korea's second nuclear test in May 2009, the U.S. and China and, to a lesser extent, Russia and Japan have continued to play a key role on the North Korean nuclear issue (Lankov 2018, 182).

Second, while South Korea has placed low strategic value on Africa, it has placed high economic value on the continent. Since the end of the Cold War, Africa has become an economic battleground for the emerging economies (e.g., 
South Korea, China, India, Russia, Turkey, and Brazil), eager to secure markets, energy, and investment opportunities to support their expanding economies (Vickers 2013, 673). South Korea may have ridden on the wave of the economic activities of other emerging powers so as not to be left out in the competition. The economic growth rate exceeding 6\% in some African countries (e.g., Benin, Côte d'Ivoire, Ethiopia, Ghana, Kenya, Rwanda, Senegal, and Uganda), the decrease in the number of conflicts in the continent, and the increasing number of special economic zones (SEZs) have raised the prospect of Africa's brighter economic future. There are estimated 237 SEZs, operating in 38 countries in Africa (United Nations Conference on Trade and Development 2020). In July 2019, the African Continental Free Trade Area went into force. Though challenges remain (e.g., external debt, high unemployment rates, and poverty, just to name a few), "GDP in Africa has grown in real terms every year since 2009" (African Development Bank Group 2018, 6; World Bank 2020). Like South Korea, other emerging powers have also engaged in active diplomacy with African states. In addition to their frequent bilateral meetings, they have regularly held multilateral forums (e.g., the China-Africa Co-operation Forum, the India-Africa Forum, the Brazil-Africa Forum, and the Turkey-Africa Economic Forum), which have mostly focused on issues related to economic and development cooperation.

Third, the priorities of bilateral meetings reflect the convergence of Africa's economic and development needs and South Korea's economic and business interests in the continent. For example, Africa's growing need for infrastructure development (e.g., roads, railroads, and ports) coincide with South Korea's search for overseas construction projects for Korean businesses "to offset the ongoing sluggishness of the domestic construction market” (Park 2013, 193). To help South Korean companies participating in construction projects avoid double taxation, many bilateral meetings with African countries have discussed the taxation issue. South Korea, as a resource-poor country, imports $97 \%$ of its energy use, mostly from the Middle East (Institute of Foreign Affairs and National Security 2011, 3). South Korea has seen Africa, endowed with large amounts of mineral and energy resources, as an alternative supplier to the Middle East, while African countries view South Korea, that usually imports crude oil, natural gas, and minerals from Africa, as a market (Kim and Gray 2016, 654). With respect to economic development, African countries identify infrastructure development, food security, rural and agricultural development, energy security, environment, and human capital development as their most acute areas to improve to reduce poverty (Park, Kim, and Jeon 2010, 27-38). Their development priorities, therefore, are consistent with the areas South Korea prioritizes for its ODA. ${ }^{3}$

Fourth, South Korea may have little leverage in persuading African countries 
to weaken their ties with North Korea. South Korea's engagement in Africa in the form of trade, investment, and ODA has been too modest to hold sway, particularly compared to China's. South Korea's trade with Africa totaled US $\$ 17.98$ billion in 2017 (International Monetary Fund 2018). Its total ODA to Africa in 2017 was US\$408.01 million (OECD 2019). In contrast, China is Africa's largest bilateral trade partner and investor (Taylor 2016, 193). China's imports and exports with Africa amounted to US\$204.19 billion in 2018 (Ministry of Commerce, People's Republic of China 2018). "By the end of 2014, a total of 3,000 Chinese enterprises had operated in Africa, providing direct investment of over \$3 billion" (Ying 2018, 36). What is more, at the 2018 summit of the Forum on China-Africa Cooperation (FOCAC), Xi Jinping promised "another US $\$ 60$ billion" to finance Africa (York 2018).

China's rise in Africa and the growing dependence of African countries on China have translated to China's political clout in the continent (York 2018). For example, while a handful of heads of government have attended the Korea-Africa Forums, almost all African heads of government have attended the FOCAC summits. One of the Chinese foreign policy goals has been isolating Taiwan. Today, eSwatini (formerly Swaziland) is the only African country maintaining diplomatic ties with Taiwan (Ibid.). African countries, "eager for Chinese funds," have switched sides (Ibid.). Unlike China, South Korea's engagement in Africa has not amounted to the level enabling the country to flex its muscles over African countries to secure their support for North Korea's denuclearization and compliance with UN sanctions. Its lack of leverage, therefore, could have made South Korea less inclined to bring up the North Korean nuclear issue, deemed less urgent to African countries than their economic and development priorities, in bilateral meetings.

Last, South Korea itself, by engaging in economic activities with North Korea, has run counter to UN sanctions on North Korea, despite its commitment to tough sanctions. According to Stanton, Lee, Klingner (2017, 71-72), "until 2016, South Korea let approximately $\$ 100$ million a year flow into Pyongyang" through the industrial complex in Kaesong, a border city in North Korea over the de-militarized zone. The two Koreas had jointly operated the complex since 2004 using South Korea's capital and North Korea's cheap labor until its closure by South Korea in February 2016 in the wake of North Korea's long-range missile test and fourth nuclear test (Easley 2016, 21). Owing to the complex, the annual volume of inter-Korean trade significantly increased even with UN sanctions in place; it rose from US\$1,350 million in 2006 to US\$2,714 million in 2015 (Ministry

${ }^{3}$ For South Korea's ODA priorities, see Korea International Cooperation Agency (2006-2018). 
of Unification 2019). Thus, sanctions had had little impact until the closure of the complex. In 2018, South Korea shipped "342.9 tons of petroleum products to North Korea" and did not report to the UN (Lee 2019). South Korea's lukewarm compliance with UN sanctions, therefore, may have made the country less inclined to urge others to implement sanctions.

\section{Difference across the administrations}

We find that there is no significant difference between hard- and soft-line administrations in addressing North Korea's nuclear issue to African states. Frequent meetings suggest that the conservative Lee and Park administrations more actively engaged in bilateral diplomacy with African states than the progressive administrations. Less frequent meetings during the Roh and Moon administrations may be, in part, due to the temporal domain of this study, which does not coincide with the dates of their administrations.

Though more engaged, the two conservative administrations differed in terms of diplomatic priorities. While over $65 \%$ of bilateral summits and foreign ministerial meetings during the Park administration either discussed the security situation on the Korean peninsula or sought African cooperation for North Korea's denuclearization and UN sanctions, the Lee administration hardly addressed those issues (Tables $2 \& 3$ ). Lee, who came from the business field, won the presidential election on a pledge to revitalize the Korean economy (Onishi 2008). For South Korea's relations with the outside world, he put forth the vision of "Global Korea" and "niche diplomacy," which would use South Korea's niche in economic development and technological advancement as a model for "international development and environmental and economic cooperation" (Kim 2016). His domestic economic concerns and focus on non-security issues with respect to South Korea's relations with developing countries, therefore, might have overshadowed the denuclearization and sanctions issues during his administration. Park, however, brought the "security reality" of the Korean peninsula to the forefront (Kirk 2012), prompted by a series of North Korea's nuclear tests, shortly before her inauguration and during her administration (third test on February 12, 2013 and fourth and fifth tests in January and September 2016, respectively). The conciliatory Roh administration, as we assume, almost did not discuss the security issues, though North Korea became a nuclear weapons state during his administration. However, the Moon administration has addressed security issues in almost all of its bilateral meetings with African countries, perhaps, triggered by the significant increase in North Korea's missile tests. However, the number of bilateral meetings it held with African countries is small (Tables $2 \& 3$ ). 
To examine the statistical significance of the difference between the progressive and conservative administrations in discussing the nuclear and sanctions issues, we use the percentage of meetings of each administration that included security discussions (Table 3) and conduct a chi-square test. The chi-square test of independence shows no significant relationship between the different approaches to North Korea and bringing up the nuclear and sanctions issues in high-level bilateral meetings. The p-value is much greater than the significance level of .1. This result implies that the different approaches to North Korea across the administrations have had little effect on South Korea's diplomatic priorities in Africa.

Table 2. Korea-Africa Bilateral Summits and Foreign Ministerial Meetings

by Administration: October 14, 2006-December 31, 2019

\begin{tabular}{|c|c|c|c|}
\hline \multicolumn{4}{|c|}{ Roh Moo-hyun (October 14, 2006-February 24, 2008) } \\
\hline \multicolumn{2}{|c|}{ Summits (9) } & \multicolumn{2}{|c|}{ Foreign Ministerial Meetings (6) } \\
\hline \multicolumn{2}{|l|}{ Level of Security } & \multicolumn{2}{|l|}{ Level of Security } \\
\hline Discussion & Frequency & Discussion & Frequency \\
\hline 0 & 5 & 0 & 3 \\
\hline 1 & 1 & 1 & 0 \\
\hline 2 & 0 & 2 & 0 \\
\hline Missing & 3 & Missing & 3 \\
\hline \multicolumn{4}{|c|}{ Lee Myung-bak (February 25, 2008-February 25, 2013)* } \\
\hline \multicolumn{2}{|c|}{ Summits (18) } & \multicolumn{2}{|c|}{ Foreign Ministerial Meetings (25) } \\
\hline \multicolumn{2}{|l|}{ Level of Security } & \multicolumn{2}{|l|}{ Level of Security } \\
\hline Discussion & Frequency & Discussion & Frequency \\
\hline 0 & 16 & 0 & 17 \\
\hline 1 & 1 & 1 & 3 \\
\hline 2 & 1 & 2 & 1 \\
\hline Missing & 0 & Missing & 4 \\
\hline \multicolumn{4}{|c|}{ Park Geun-hye (February 25, 2013-March 10, 2017)* } \\
\hline \multicolumn{2}{|c|}{ Summits (16) } & \multicolumn{2}{|c|}{ Foreign Ministerial Meetings (29) } \\
\hline \multicolumn{2}{|l|}{ Level of Security } & \multicolumn{2}{|l|}{ Level of Security } \\
\hline Discussion & Frequency & Discussion & Frequency \\
\hline 0 & 7 & 0 & 8 \\
\hline 1 & 3 & 1 & 7 \\
\hline 2 & 6 & 2 & 14 \\
\hline Missing & 0 & Missing & 0 \\
\hline
\end{tabular}




\begin{tabular}{cc|cc}
\hline \multicolumn{4}{c}{ Moon Jae-in (May 10, 2017-December 31, 2019) } \\
\hline Summits (4) & Foreign Ministerial Meetings (10) \\
\hline Level of Security & Level of Security \\
Discussion & Frequency & Discussion & Frequency \\
0 & 0 & 0 & 1 \\
1 & 0 & 1 & 7 \\
2 & 4 & 2 & 1 \\
Missing & 0 & Missing & 70 \\
\hline Total & 47 & Total & 7
\end{tabular}

Notes: *denotes the conservative administration. 0 refers to meetings with no discussion either on denuclearization or UN sanctions; 1, meetings involving a broad discussion on the security situation on the Korean Peninsula; and 2, meetings involving a discussion seeking African cooperation for North Korea's denuclearization and compliance with UN sanctions on North Korea.

Table 3. Meetings Discussing Security Issues as a Percentage of Total Korea-Africa Bilateral Summits and Foreign Ministerial Meetings by Administration: October 14, 2006-December 31, 2019

\begin{tabular}{cccccc} 
& & $\begin{array}{c}\text { Foreign } \\
\text { Ministerial }\end{array}$ & & \multicolumn{2}{c}{$\begin{array}{c}\text { Meetings } \\
\text { with Security }\end{array}$} \\
\hline Administration & Summits & Meetings & Total & Discussion & $\%^{*}$ \\
\hline Roh Moo-hyun & 6 & 3 & 9 & 1 & 11.11 \\
Lee Myung-bak & 18 & 21 & 43 & 6 & 13.95 \\
Park Geun-hye & 16 & 29 & 45 & 30 & 66.67 \\
Moon Jae-in & 4 & 9 & 13 & 12 & 92.31 \\
\hline
\end{tabular}

*The percentages are calculated excluding the missing cases.

\section{CONCLUSION}

This study examined the extent to which South Korea has used high-level bilateral face-to-face meetings as a foreign policy tool to seek African cooperation for North Korea's denuclearization and to dissuade African countries from helping North Korea evade UN sanctions. We find that economic and commercial diplomacy has been a dominant feature of South Korea's bilateral diplomacy with African countries, while North Korea's denuclearization and UN sanctions, overall, have received only peripheral attention even in the meetings where those security issues were addressed. Furthermore, there is no significant difference between the progressive and conservative administrations in this trend. These findings imply that South Korea has underutilized its high-level bilateral meetings with African countries as an intention signaling mechanism to seek 
their cooperation on enforcing UN sanctions.

The country has placed a premium on the U.S., China, Japan, and Russia in dealing with the North Korean nuclear issue. Its diplomatic concentration on these four countries, however, has made no progress toward North Korea's denuclearization and therefore has been unavailing. North Korea's unremitting weapons tests in defiance of UN Security Council resolutions and the demolition of the joint liaison office on June 16, 2020 rather suggest that its denuclearization is not even on the distant horizon. In this regard, South Korea may be in ever increasing need to expand the scope of its security diplomacy by including other players to strengthen the sanctions regime and to form a larger coalition for North Korea's denuclearization. African countries may be a force to be reckoned with, even though it is unlikely for them to bring about North Korea's denuclearization. Considering that they have served North Korea as financial lifelines and make up a significant voting bloc in the UN General Assembly and Security Council, South Korea needs Africa's strong commitment to North Korea's denuclearization and implementation of UN sanctions to put further pressure on North Korea to change its course. The type of relationship North Korea and African countries have built over time is a tough one for South Korea to deal with. South Korea needs to ramp up its use of bilateral high-level meetings to draw out Africa's strong commitment. 


\section{REFERENCES}

African Development Bank Group. 2018. African Economic Outlook 2018. Accessed at https://www.afdb.org/fileadmin/uploads/afdb/Documents/Publications /African_Economic_Outlook_2018_-_EN.pdf (August 18, 2019).

Bechtol, Bruce. 2018. North Korean Military Proliferation in the Middle East and Africa: Enabling Violence and Instability. Lexington, Kentucky: University Press of Kentucky.

Bergeijk, Peter A. G. VAN. 1989. "Success and Failure of Economic Sanctions.” Wi ley Online Library. Accessed at https://onlinelibrary.wiley.com/doi/pdf/1 0.1111/j.1467-6435.1989.tb00200.x (August 8, 2018).

Cho, Seong-ryoul. 2018. "International Politics of the Denuclearization Process of the Korean Peninsula: Comparative Case Studies." Diplomacy 126, 23-42. (In Korean)

Choe, San-Hun. 2016. "U.S. and South Korea to Seek Strong Punishment over North's Nuclear Test.” New York Times (September 13). Accessed at https://www.nytimes.com/2016/09/14/world/asia/north-korea-sanctions -nuclear-bombers-un.html (August 8, 2018).

Cheong Wa Dae. Speeches, Remarks \& Briefings. Accessed at http://english1.president.go.kr/BriefingSpeeches/Speeches (multiple days).

Cordier, Andrew. 1963. "Diplomacy Today." Journal of International Affairs17(1), 1-8.

Crabtree, Justina. 2018. "North Korea and Zimbabwe: A Friendship Explained." CNBC (July 17). Accessed at https://www.cnbc.com/2018/07/17/north-koreaand-zimbabwe-a-friendship-explained.html (May 24, 2020).

Delury, John. 2013. “Delivering on the Promise of Trustpolitik: Park Geun-hye's Daunting Challenge on the Korean Peninsula." American Foreign Policy Interests 35 , 155-159.

DuPre, Annie, Nicolas Kasprzyk, and Noel Stott. 2016. "Cooperation between Afr ican states and the Democratic People's Republic of Korea." Institute for Security Studies. Accessed at https://issafrica.ss.amazon.com/site/uploads/ research-report-dprk.pdf (April 26, 2019).

Easley, Leif-Eric. 2016. "Kaesong and THAAD: South Korea's Decisions to Counter the North." World Affairs 179(2), 21-27.

Giauque, Jeffrey G. 2001. "Bilateral Summit Diplomacy in Western European and Transatlantic Relations, 1956-63.” European History Quarterly 31(3), 427-445. 
Haggard, Stephan. 2017. "Limited Options: Trump and the North Korea Conundrum.” Global Asia 12(4), 48-51.

Hall, Todd and Keren Yarhi-Milo. 2012. “The Personal Touch: Leaders' Impression, Costly Signaling, and Assessment of Sincerity in International Affairs.” International Studies Quarterly 56(3), 560-573.

Holmes, Marcus. 2013. "The Force of Face-to-Face Diplomacy: Mirror Neurons and the Problem of Intentions." International Organization 67(4), 829-861.

Holmes, Marcus. 2018. Face-to-Face Diplomacy. Cambridge, United Kingdom: Cambridge University Press.

Hwang, Kyu-Deug. 2014. "Korea's Soft Power as an Alternative Approach to Africa in Development Cooperation." African and Asian Studies 13(3), 249-271.

Institute of Foreign Affairs and National Security (IFAN). 2011. Energy Diplomacy in the Middle East and Africa: Turkey, Iran, Ethiopia, Angola, and South Africa. Seoul, Korea: IFAN. (In Korean)

International Monetary Fund. 2018. Direction of Trade Statistics Yearbook. Accessed

https://data.imf.org/?sk=9D6028D4-F14A-464C-A2F2-59B2CD424B85 (February 29, 2020).

Jung, Changkuk, Wonbin Cho, and Wonjae Hwang. 2018. "Does Official Development Assistance Promote Foreign Policy Cooperation from its Recipients? The Case of South Korea.” Pacific Focus 33(1), 83-110.

Kang, Gil Seong. 2011. "The Korea-Africa Partnership: Beyond Trade and Invest ment." Africa Economic Brief. Accessed at https://www.afdb.org/fileadm in/uploads/afdb/Documents/Publications/AEB\%20VOL\%202\%20Issue\% 209\%20June\%202011_AEB\%20VOL\%202\%20Issue\%209\%20June\%20201 1.pdf (August 10, 2018).

Kasprzyk, Nicolas. n.d. "Africa's role in Strengthening Sanctions Against North Korea.” Institute for Security Studies. Accessed at https://issafrica.org/amp /iss-today/africas-role-in-strengthening-sanctions-against-north-korea (July 5, 2021).

Kim, Hong Nack. 2006. "South-North Korean Relations Under The Roh Moo-Hyun Government.” International Journal of Korean Studies 5(1), 37-59.

Kim, Inhan. 2018. "No More Sunshine: The Limits of Engagement with North Korea.” Washington Quarterly 40(4), 165-181.

Kim, Soyeun and Kevin Gray. 2016. "Overseas Development Aid as Spatial Fix? Examining South Korea's Africa Policy.” Third World Quarterly 37(4), 
649-664.

Kim, Sung-Mi. 2016. "South Korea's Middle-Power Diplomacy: Changes and Challenges." Chatham House Asia Programme. Accessed at https://www.chathamhouse.org/sites/default/files/publications/researc h/2016-06-22-south-korea-middle-power-kim.pdf (June 6, 2020).

Kirk, Donald. 2012. "South Korea's President-Elect Promises New Era of Change." Christian Science Monitor (December 20). Accessed at https://www.csmonitor.com/World/Asia-Pacific/2012/1220/South-Korea -s-president-elect-promises-new-era-of-change (March 12, 2020).

Korea International Cooperation Agency. 2006-2018. KOICA Annual Report. Accessed at http://www.koica.go.kr/koica_en/3492/subview.do (February 29, 2020).

Lankov, Andrei. 2018. "The North Korean Denuclearization: The Russian Perspectives.” Foreign Relations 20(1), 162-182.

Lebovic, James H. and Elizabeth N. Saunders. 2016. "The Diplomatic Core: The Determinants of High-Level US Diplomatic Visits, 1946-2010.” International Studies Quarterly 60(1), 107-123.

Lee, Donna and David Hudson. 2004. "The Old and New Significance of Political Economy in Diplomacy.” Review of International Studies 30(3), 343-360. Lee, Ho-young. 2011. "Korea's Policies on Africa: Development of Energy and Resources Diplomacy.” Korea Focus 19(4), 87-97.

Lee, Joyce. 2019. "South Korea 'Selective' in Implementing Sanctions on North-group." Reuters (January 23). Accessed at https://www.reuters.com/article/us-northkorea-southkorea-sanctions/s outh-korea-selective-in-implementing-sanctions-on-north-group-idUS KCN1PH0D4 (August 16, 2019).

Ministry of Commerce (People's Republic of China). 2018. "Statistics on China-Africa Trade in 2018." Accessed at http://english.mofcom.gov.cn/article/statistic/lanmubb/AsiaAfrica/2019 01/20190102831255.shtml (August 15, 2019).

Ministry of Foreign Affairs. 2006-2017. Chronology of Diplomacy. Seoul, Korea: Ministry of Foreign Affairs.

2006-2019. Diplomatic White Paper. Seoul, Korea: Ministry of Foreign Affairs.

Ministry News (for press releases and briefings). Accessed at http://www.mofa.go.kr/eng/brd/m_5674/list.do (multiple days).

. 2020. "Understanding the North Korean Nuclear Issue." Accessed at http://www.mofa.go.kr/eng/wpge/m_5474/contents.do (January 5, 2020). Ministry of Unification. 2019. “Inter-Korean Exchanges \& Cooperation.” Accesse 
$\mathrm{d}$ at https://www.unikorea.go.kr/eng_unikorea/relations/statistics/excha nges/ (August 17, 2019).

Moon, Chung-in. 2011. "Between Principle and Pragmatism: What Went Wrong with the Lee Myung-bak government's North Korean Policy?” Journal of International and Area Studies 18(2), 1-22.

Organization for Economic Co-operation and Development (OECD). 2019. "Aid (ODA) Disbursements to Countries and Regions." OECD Stat. Accessed at http://stats.oecd.org/Index.aspx?DatasetCode=TABLE2A (August 15, 2019).

Onishi, Norimitsu. 2008. "South Korean President Pledges Pragmatism.” New York Times (February 26). Accessed at https://www.nytimes.com/2008/02/26/ world/asia/26korea.html (August 21, 2019).

Owoeye, Jide. 1991. “The Metamorphosis of North Korea's African Policy.” Asian Survey31(7), 630-645.

Park, Chan-bong. 2008. “The Lee Administration's Policy toward North Korea: Directions and Tasks." Korean Observations on Foreign Relations 10(1), 6-27.

Park, Young Ho. 2013. "Perspectives of Korea-Africa Economic Cooperation." Korean Observations on Foreign Relations 15(1), 187-211.

Park, Young Ho, Minhee Kim, and Hyelin Jeon. 2010. The Strategy for Economic and Development Cooperation between Korea and Major African Countries: Ghana, DRC, South Africa, Ethiopia. Seoul, Korea: Korea Institute for International Economic Policy.

Pitcher, M. Anne and Kelly M. Askew. 2006. "African Socialisms and Postsocialisms." Africa: Journal of the International African Institute 76(1), 1-14.

Roehrig, Terence. 2013. "South Korea, Foreign Aid, and UN Peacekeeping: Contributing to International Peace and Security as a Middle Power." Korea Observer44(4), 623-645.

Rozental, Andrés and Alicia Buenrostro. 2013. "Bilateral Diplomacy." In Andrew F. Cooper et al. eds., The Oxford Handbook of Modern Diplomacy, Oxford: Oxford University Press.

Security Council Report. 2021. UN Documents for DPRK (North Korea). Accessed at https://www.securitycouncilreport.org/un-documents/dprk-northkorea/ (January 8, 2021).

Sieff, Kevin. 2017. "North Korea's Surprising, Lucrative Relationship with Africa." Washington Post (July 10). Accessed at https://www.washingtonpost. com/world/africa/north-koreas-surprising-lucrative-relationship-withafrica/2017/07/10/c4e6f65d-30fe-4bd2-b178-d90daaac3007_story.html?u 
tm_term=.c6d3620b139fll (October 14, 2017).

Stanton, Joshua, Sung-Yoon Lee, and Bruce Klingner. 2017. "Getting Tough on North Korea: How to Hit Pyongyang Where It Hurts." Foreign Affairs 96(3), 65-75.

Tago, Atsushi. 2017. "Multilateralism, Bilateralism, and Unilateralism in Foreign Policy." Oxford Research Encyclopedia of Politics. DOI: 10.1093/acrefore/9780190228637.013.449.

Taylor, Ian. 2016. "Africa After the China Boom." Current History 115(781), 193-195.

United Nations Conference on Trade and Development. 2020. "Foreign Direct Investment to Africa Defies Global Slump, Rises 11\%." Accessed at https://unctad.org/en/pages/newsdetails.aspx?OriginalVersionID=2019 (February 24, 2020).

United Nations Security Council. 2019a. "Resolutions." Accessed at https://www.un.org/securitycouncil/content/resolutions (April 25, 2019). 2019b. "Reports." Accessed at https://www.un.org/securitycouncil/sanct ions/1718/panel_experts/reports (April 25, 2019).

Verdier, Daniel. 2008. "Multilateralism, Bilateralism, and Exclusion in the Nuclear Proliferation Regime." International Organization 62(3), 439-476.

Vickers, Brendan. 2013. "Africa and the Rising Powers: Bargaining for the 'Marginalized Many'." International Affairs 89(3), 673-693.

World Bank. 2020. GDP Growth (Annual \%)-Sub-Saharan Africa. Accessed at https://data.worldbank.org/indicator/NY.GDP.MKTP.KD.ZG?locations=Z G (February 13, 2020).

Ying, Zhang. 2018. "China’s Diplomacy in Africa: Ideas and Practices." China International Studies 69, 28-46.

Yoon, Mi Yung and Chungshik Moon. 2014. "Korean Bilateral Official Development Assistance to Africa Under Korea's Initiative for Africa's Development.” Journal of East Asian Studies 14(2), 279-301.

York, Geoffrey. 2018. "China Flexes Its Political Muscles in Africa with Media Cen sorship, Academic Controls." Globe and Mail Inc. (October 11). Accessed at https://www.theglobeandmail.com/world/article-china-flexes-its-pol itical-muscles-in-africa-with-media-censorship/ (August 12, 2019). 